\title{
Comentarii asupra surselor Lexiconului slavon-rutean al lui Pamvo Berînda
}

\author{
Alexander Levichkin ${ }^{\star}$ \\ Institutul de Studii Lingvistice, Academia Rusă de Științe, Tuchkov pereülok 9, 199053 Sankt-Petersburg, Rusia
}

$\begin{array}{ll}\text { Despre articol } & \text { Rezumat } \\ \text { Istoric: } & \text { Articolul examinează cîteva dintre sursele Lexiconuluislavon-rutean al lui Pamvo } \\ \text { Primit 21 septembrie 2021 } & \text { Berînda. Identificarea surselor dicționarului și a tuturor citatelor ascunse este } \\ \text { Acceptat 30 septembrie 2021 } & \text { o sarcină importantă pentru prezentarea corectă a materialelor acestui monu- } \\ \text { Publicat 12 decembrie 2021 } & \text { ment lexicografic. Materialele citate prezentate în Lexicon sînt împărțite în două } \\ & \text { grupe: materiale care nu au indicată sursa (un exemplu este Tălmăcirea vorbelor } \\ \text { Cuvinte-cheie: } & \text { greu de înțeles) și materiale care au indicată sursa. Pentru al doilea caz este fur- } \\ \text { lexicologie istorică } & \text { nizată o listă neexhaustivă a unor asemenea exemple. Astfel de citate arată că } \\ \text { documente vechi } & \text { Berînda a folosit în Lexiconul său în primul rînd lucrări la tipărirea cărora a par- } \\ \text { filologie } & \text { ticipat el însuși. Acestea sînt Comentariul la Faptele Apostolilor și Comentariul } \\ \text { editarea textelor } & \text { la cele 14 Epistole ale Sfintului Apostol Pavel, ambele aparținînd lui Ioan Gură } \\ & \text { de Aur, și Evanghelia didactică. Utilizarea intrărilor de dicționar din Tălmăcirea } \\ & \text { vorbelor greu de ințeles, lexicon întocmit în baza vocabularul din Scara Raiului, } \\ & \text { și din Tălmăcirea numelor după alfabet a lui Maxim Grecul confirmă interesul } \\ \text { lui Berînda, indicat și de alți cercetători, pentru tradiția lexicografică anterioară. }\end{array}$

\section{Introducere}

Ediția critică a Lexiconului slavon-rutean al lui Pamvo Berînda (în continuare: Lexicon) în format tipărit și electronic rămîne un obiectiv important și în ziua de astăzi. Pentru o ediție detaliată este necesar, mai întîi, a studia principiile de alcătuire a Lexiconului, selecția lexicului, structura intrărilor de dicționar, sistemul de notare, izvoarele și alte caracteristici ale dicționarului. Articolul de față își propune să prezinte cîteva surse ale Lexiconului lui Berînda.

Pamvo Berînda însuși face o mențiune scurtă despre sursele Lexiconului în introducerea la dicționarul respectiv (aici și în ceea ce urmează sînt utilizate materiale extrase din ediția Lexiconului lui Berînda publicată în 1627, exemplarul Bibliotecii Naționale din Rusia, II.5.21a) și într-un alt articol de la sfîrșitul

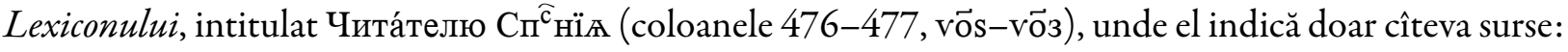
Lexisul lui Lavrentii Zizanii (Vilno, 1596), Biblia de la Anvers, Maxim Grecul, Manuil Retorul, Comentariul la Faptele Apostolilor și Comentariul la Epistolele Apostolilor. Acest aspect a fost remarcat și de alți cercetători ai Lexiconului (vezi Arkhangel'skiŭ, 1902; Janów, 1951; Nimciuk, 1961). Dintre studiile moderne subliniem articolul lui Kalugin (2014), care consideră dicționarul lui Maxim Grecul intitulat Tălmăcirea numelor după alfabet drept una dintre sursele Lexiconului.

\section{Surse nemenționate în intrările lexiconului}

După cum au remarcat cercetările anterioare, Berînda nu menționează sursa materialelor sale din toate intrările de dicționar. Un exemplu în acest sens îl constituie Tălmăcirea vorbelor greu de ințeles, lucrare creată pe baza materialelor din Scara Raiului a lui Ioan Scărarul, monument publicat și comentat în Kovtun (1963, p. 216-268, 421-431). O parte dintre aceste articole fac trimitere către Scara Raiului, de exemplu în următoarele intrări (aici și în ceea ce urmează, între paranteze triunghiulare vom indica numărul coloanei și pagina din ediția Nimciuk (1961):

\footnotetext{
*Adresă de corespondență: alevi66@gmail.com.
} 


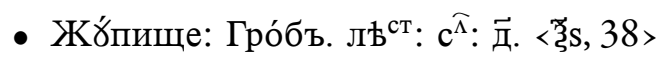

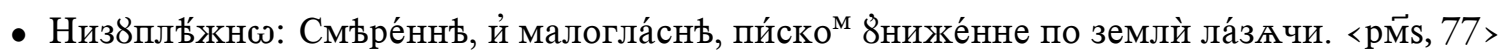

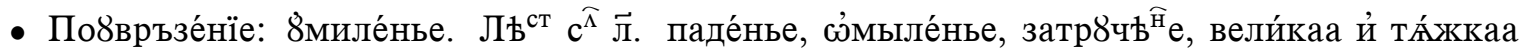
ต’спа́лость. <рӧв, 90>

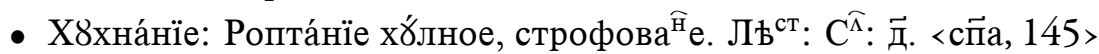

Alte intrări, care uneori extind traducerea, nu au nicio indicație referitoare la sursă, de exemplu:

- Бо́хма: Ве́сма, зго́ла, напра́сно, <ёi, 12> (cf. Kovtun, 1963, p. 429)

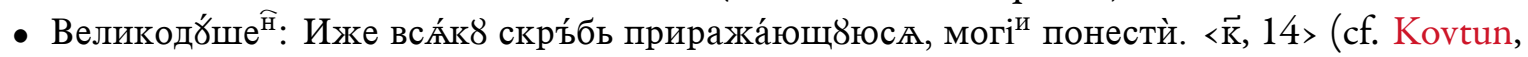
1963, p. 431)

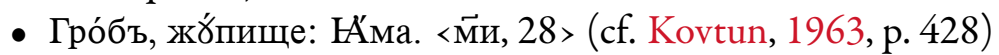

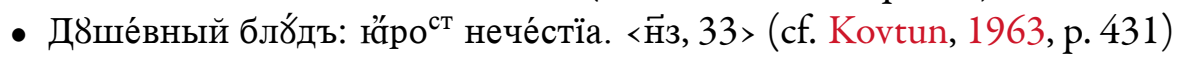

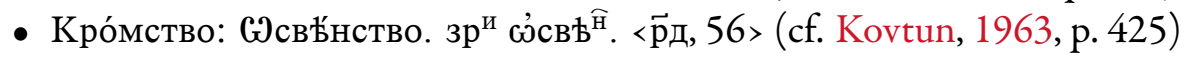

- Сме́рчъ: Піа́вица, о̋блакъ дожде́вный, ф8ртйна. <ск̄s> (cf. Kovtun, 1963, p. 424)

- Рњсноти́вїе: Истинню. <сёі, 110> (cf. Kovtun, 1963, p. 429)

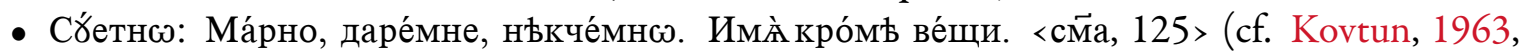
p. 430)

- Съста́въ, v́по́стась, со́бство: Персо́на, ஸ’сóба, лицѐ. с́ста́въ в члต́нка е́леме́н ${ }^{\mathrm{T}}$. Съста́въ вю

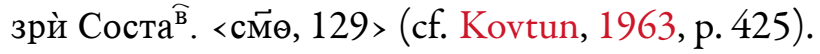

Un alt izvor posibil utilizat de către Berînda îl reprezintă scrierile despre gramatică. Se poate presupune faptul că el a folosit materialul din volumele „Грамматика Словенска Съвершше́нна ${ }^{\overparen{\Gamma}}$ йскӧ́ства о̆смй

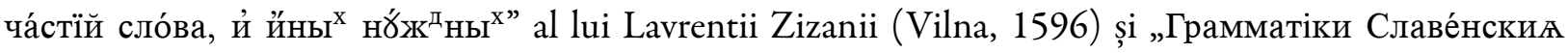
пра́вилное Cи́нтагмма" al lui Meletie Smotrițki (Vievis, 1619) (publicate în Kuzminova, 2000) sau Adelfo-

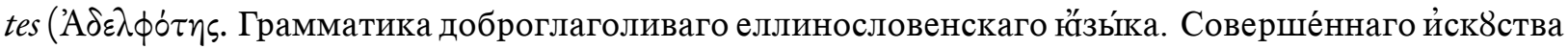
о’смѝ часте́й сло́ва. Ко наказа́нию многоимени́том8 Ро ${ }^{\widehat{c}}$ сійском8 ро́дช́) (Lviv, 1591). Indicațiile cu privire la „gramatică” și „ortografie” sînt rare; de exemplu:

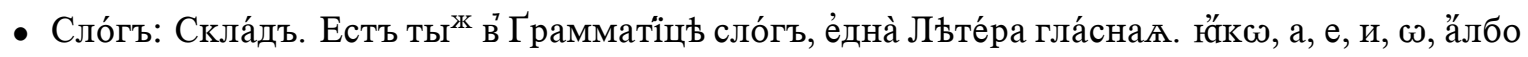

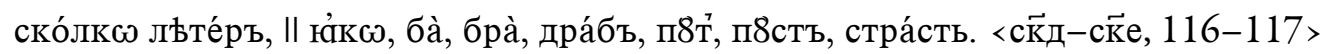

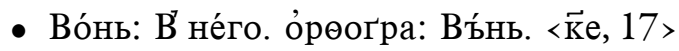

Indicațiile la utilizarea gramaticilor se evidențiază în note cu caracter gramatical:

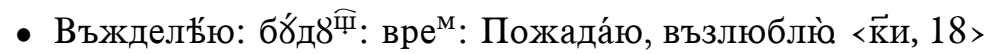

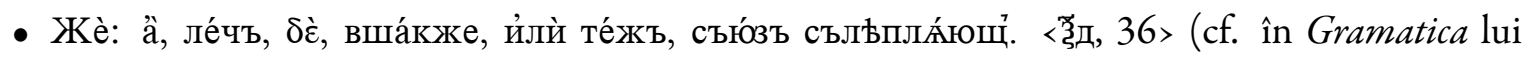
Lavrentii Zizanii: Кî^ с8тъ съльплА́ющіА; й, оӳбо, жѐ. (foaia 84), Kuzminova, 2000, p. 104)

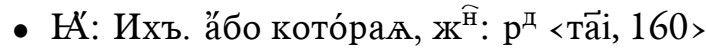

- не́же: ä, сре $\mathrm{e}^{\text {म: }}$ ро

În cele ce urmează, ne vom referi la sursele menționate în intrările de dicționar. Aici Berînda, ca în multe alte locuri, folosește prescurtări la notarea surselor, ceea ce poate crea dificultăţi în identificarea acestora. Uneori, el poate altera modalitatea de prescurtare, precum și organizarea lor. În cazul izvoarelor tipărite se menționează „foaia” ediției (prin „foaie” se pot înțelege pagina sau coloana), iar citatele din surse urmează, cîteodată, după denumirea sursei.

Printre izvoarele folosite, cel mai simplu de diferențiat sînt edițiile tipărite care au o trimitere către foaie. Așadar, se pot indica următoarele ediții: Ioan Gură de Aur, Comentariul la Faptele Apostolilor (Kiev, 1624), e.g.: 


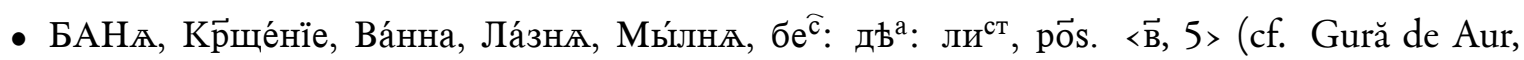

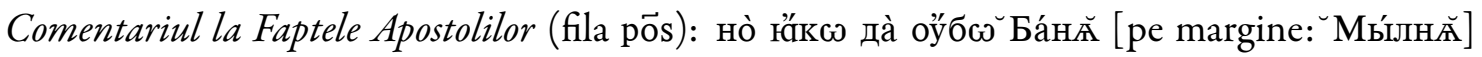
ббйдетъ.)

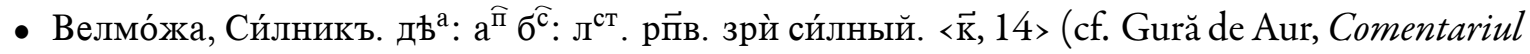
la Faptele Apostolilor (foaia рп̆в): И сѐ Мช́жъ ЕөіоплАни́нъ Еvн8хъ, речѐ, сси́лникъ̆ [marginal: велмо́жӑ] Канда́кии Цари́ци Еөіо́пскїґ.)

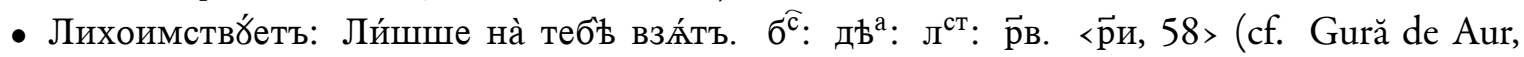

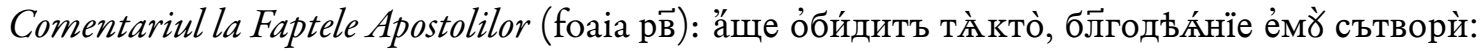
ӓще лихоимствб̈етъ, бл̈гословѝ.)

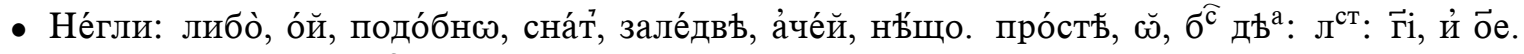

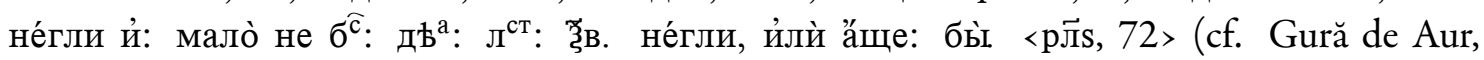

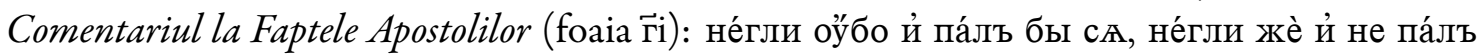

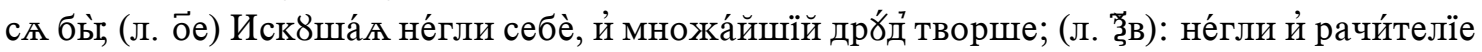
бы́сте п8сть́нніїи.)

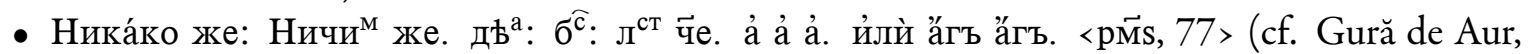

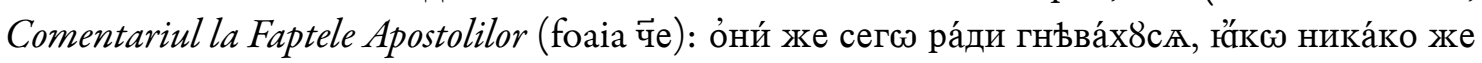
йхъ боќх8с⿱氏丶).)

O altă ediţie tipărită des utilizată de către Berînda este Comentariul la cele 14 Epistole ale Apostolului Pavel al lui Ioan Gură de Aur (Kiev, 1623), e.g.:

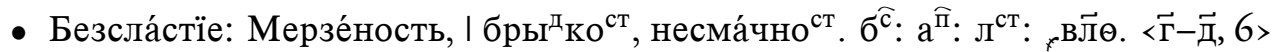

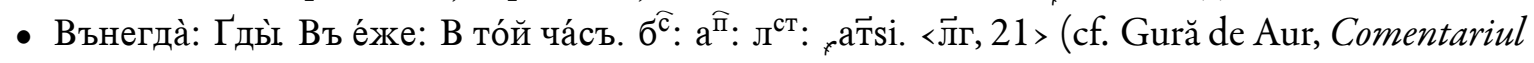
la Epistole (coloana ${ }_{r}$ aTsi): й мзда́ же внегда̀ твори́ти до́брь)

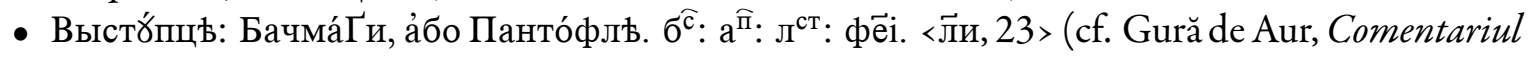
la Epistole (coloana ${ }_{r}$ фёi): И па́ки ёст нЊ̆кто, высо́къ мถ̌рою телесѐ. йнъ же кра́токъ сь́й, възе́мъ Высотйпцъ, высоча́шый быва́ет.)

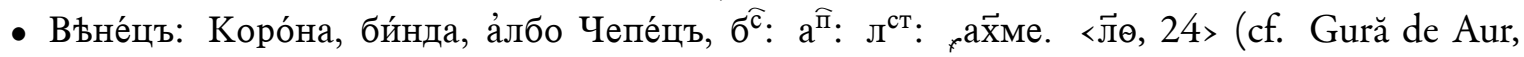

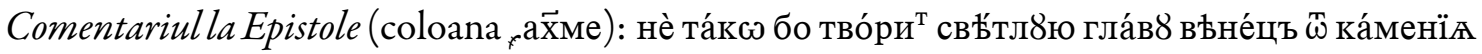
сло́женый с’болежа́щый)

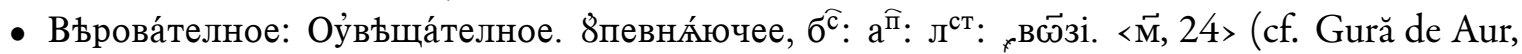

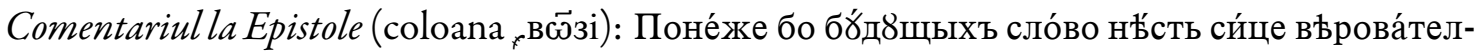
ное)

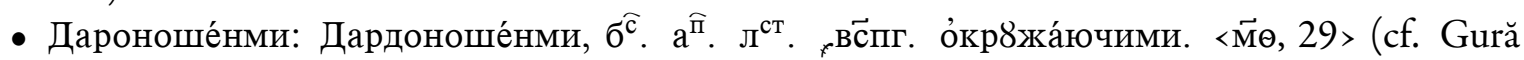

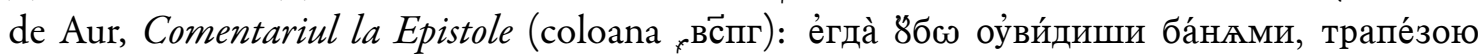
многоцьнною, и́лѝ дароноше́нми йными наслажда́ющас凡 о̋нсиц8)

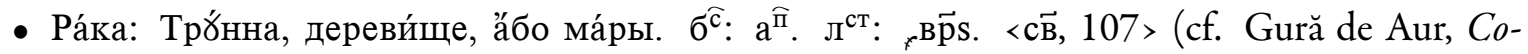
mentariul la Epistole (coloana ${ }_{f}$ в $\overrightarrow{p s}$.): семठั погребе́нїю нй ри́зъ, нѝ ра́ки, нй йного чесо́го $\vec{\omega}$ тако́вы ${ }^{\mathrm{x}}$ потре́ба).

Printre mențiunile surselor se găsesc trimiteri care conțin numai numărul indicînd coloana din cartea tipărită. Astfel de referințe sînt multiple și fac o trimitere, de asemenea, către ediția menționată mai sus:

- Загражда́ю: За8жа́ю, встог. <о̄a, 40> (cf. Gură de Aur, Comentariul la Epistole (coloana ${ }_{r}$ вС̈ог.): Ей, речѐ, но̀ та́к๗ ЕллинскаА лБпо бъ загради́ти оу́ста̀.)

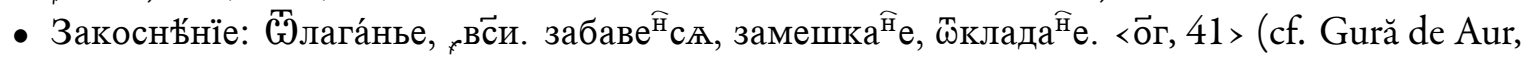
Comentariul la Epistole (coloana ${ }_{r}$ ВСи): па́че жѐ й закоснйнїе съпрАта̀ внегда̀ рещѝ.)

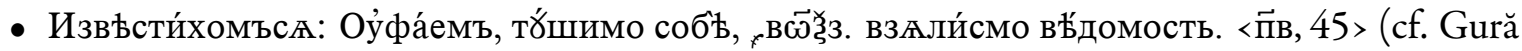
de Aur, Comentariul la Epistole (coloana ${ }_{f}$ вси): Извъсти́хомъ же с^ є’ ва́съ, възлюбле́ннїи). 
Există și cîteva trimiteri către Evanghelia didactică (Krîlos, Tipografia de pe lîngă Biserica Adormirii Maicii Domului, 1606), e.g.:

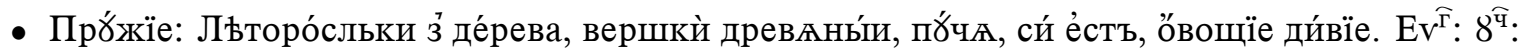
$\mathrm{He}^{\text {म}}:$ пре $\mathrm{e}^{\text {д }}$ кре

- НАзА, привре́менное страда́нїе и́ см8ще́нїе тظ́ла. хоро́ба, коро́ткое зболе $\mathrm{H}^{\widehat{\mathrm{e}}}$ тถ̆ла. а̋бо

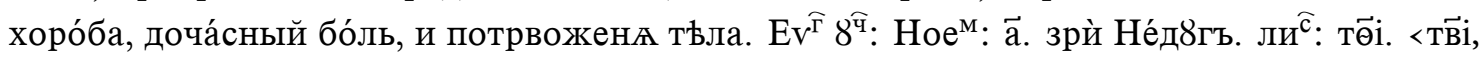
160>

O referință cu mențiunea „foaie” trimite către o ediţie tipărită a Acatistului:

Прило́гъ: Приложе ${ }^{\widehat{\mathrm{H}}}$, приточе $\mathrm{H}^{\widehat{\mathrm{H}}}$, по ${ }^{\text {म }}$ дава ${ }^{\widehat{\mathrm{H}}}$ e, зара́за, хоро́ба, сп8ще́нье, спое́нье, склне́нье, оўдаре́нье, натертьѐ, оу́та́рчка, ча́та, при́кладъ, прида́ток̉, Тира́нское оу́тисне́нье. намъ̆́т-

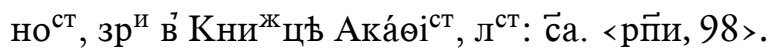

Referințele care nu menționează „foaia” nu trimit către volume tipărite, ci către manuscrise. Printre acestea observăm următoarele trimiteri:

Avva Dorotheus:

- Б8бре́ги: Ны́рки. Доро ${ }^{\widehat{\Theta}}: \Gamma^{\widehat{\Lambda}}: \vec{\Gamma}$. <ёi, 12>

- Стрб̈чецъ: стр8чо́къ. ки́стка, пе́ндзликъ. До ${ }^{\widehat{p}}:$ гі. <сл̈з, 123>

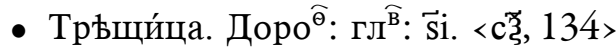

Andrei din Creta:

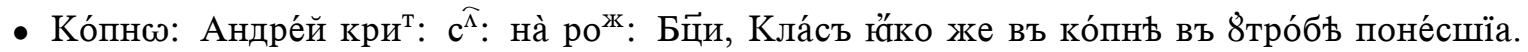
Полбикопо ${ }^{\widehat{\mathrm{K}}} .<\overrightarrow{\mathrm{p}}, 54>$

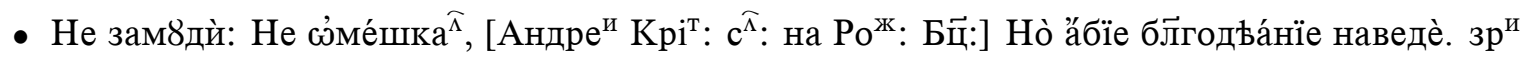
м8дне́нїе. 〈рлй, 73>

Vasile cel Mare:

- Блбйдникъ: Вшете́чникъ, вы́рва, ло́тръ <>. НАко äще Жена̀ и́дюлюсл8жи́телА Мช́жа раз-

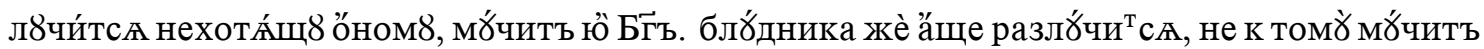

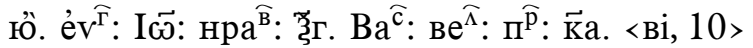

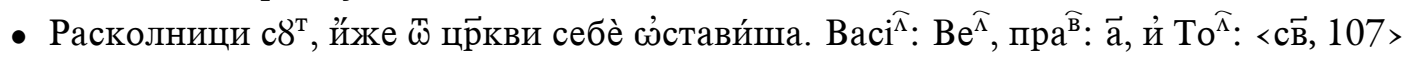

Gherman al Constantinopolului (Tălmăcirea Liturghiei):

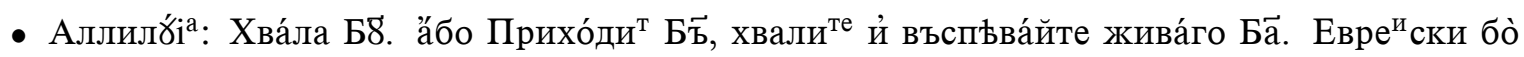

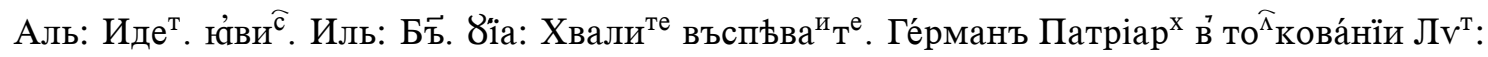

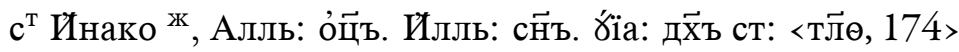

Grigorie Teologul (16 cuvîntări ale lui Grigorie Teologul cu tălmăcirile lui Nichita din Heracleea):

- Безче́стїе, досажде́нїе. Зелжи́вость, срамо́та. Безче́стїе е ${ }^{\text {ст }}$, слове́сн8 молча́ти, ต́ йх же

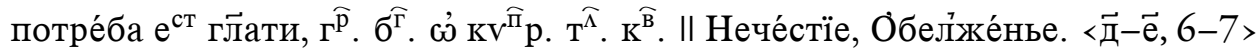

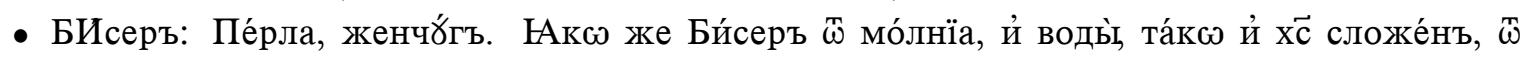

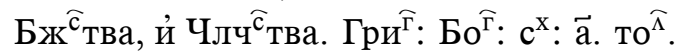

- Гада́нїе ёсть: юُже съ начерта́ема въ Гада́нїи, и́ неизґвлА́ема ве́щъ. Гри $\overrightarrow{\mathrm{K}} 3 .<\overrightarrow{\mathrm{M}} \mathrm{a}, 25>$ 


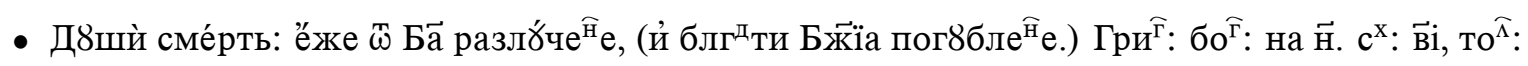
$\langle\overrightarrow{\mathrm{H}} 3,33>$

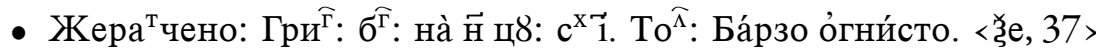

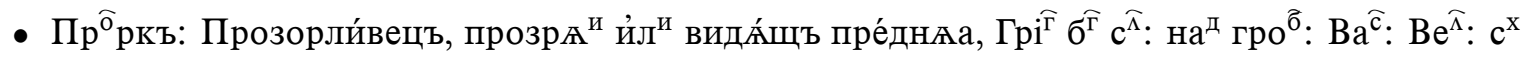
Ки. <рче, 102>

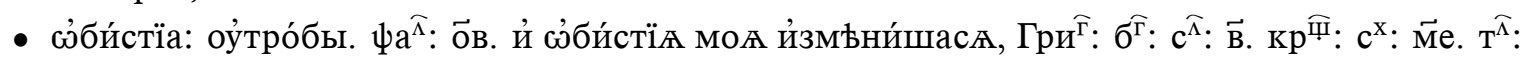
<cпs, 147>

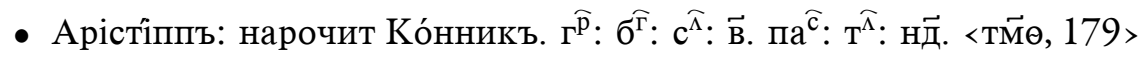

Efrem Sirul:

- Жи́то: Имъ̆нїе. е̇фре ${ }^{\mathrm{M}}: \mathrm{c}^{\widehat{\Lambda}}: \vec{\Gamma} \cdot\left\langle\mathrm{\zeta}_{3}, 38>\right.$

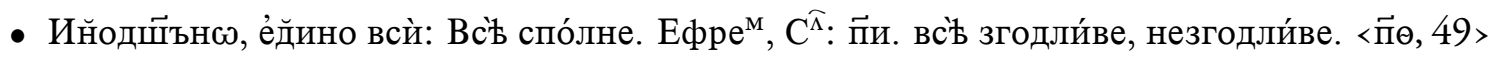

- Инодшныны ${ }^{\mathrm{n}}$ Едномь́ссны ${ }^{\mathrm{n}}, \mathrm{c}^{\widehat{\Lambda}}: \overrightarrow{\text { ми. }} \mathrm{e}^{\Phi}$ : згодный. ӓлбо и́на́кшого Ұмысл8, незгодли́вый. $\langle\vec{\Pi} \Theta>$

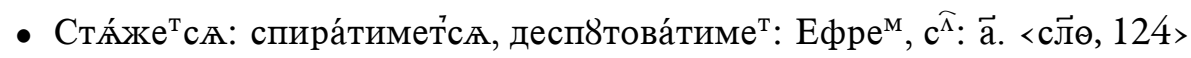

Ioan Damaschinul (Expunerea exactă a credinței ortodoxe; posibil, și alte scrieri):

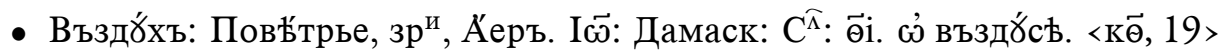

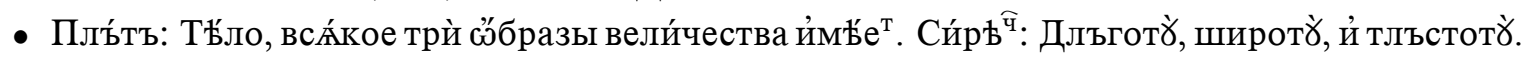
I $\overrightarrow{0}: Д \mathrm{a}^{\mathrm{M}}: \mathrm{KH}^{\widehat{\Gamma}}: \overrightarrow{\mathrm{B}} \cdot \Gamma^{\widehat{\Lambda}} \cdot \vec{\Gamma} \cdot\langle\mathrm{pH} 3\rangle$

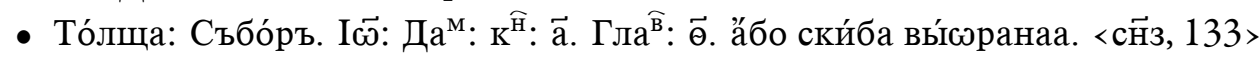

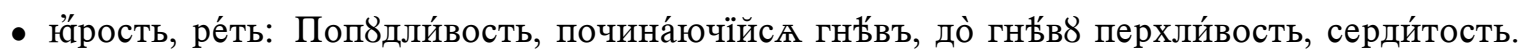

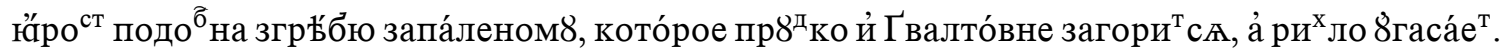

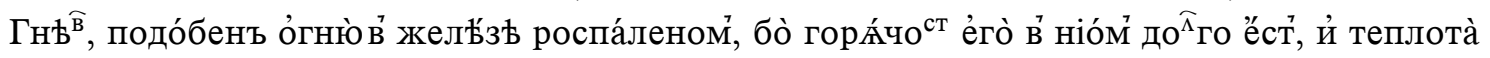

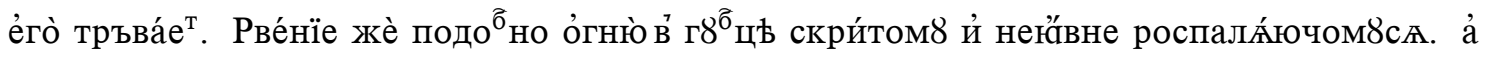
до чого̀ при ${ }^{\mathrm{T}}$ кне́тсґ всѐ па́литъ, й на

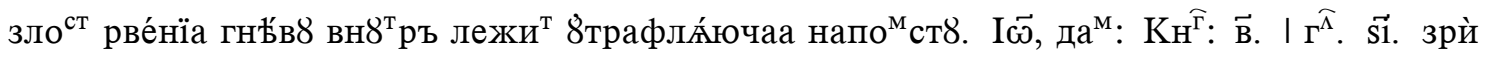
чревоюбаде́нїе. 〈тतі-тдїі, 161>

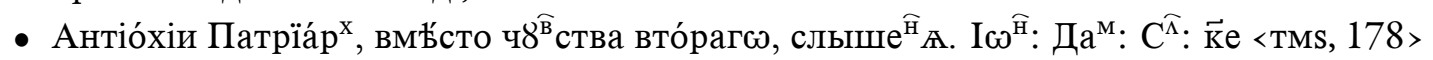

Ioan prezbiterul și exarhul Bulgariei (Introducere la Evanghelia tălmăcită; în prezent există dubii privind această atribuire auctorială):

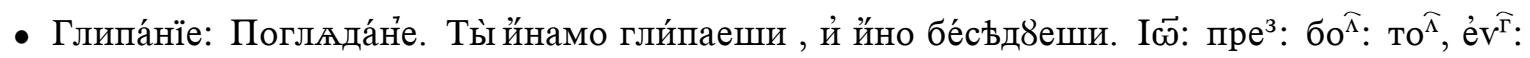
про $\mathrm{A}^{\widehat{A}}:\langle\overrightarrow{\mathrm{MB}}, 25>$

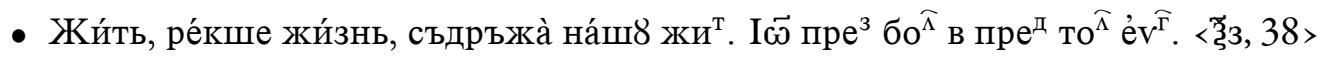

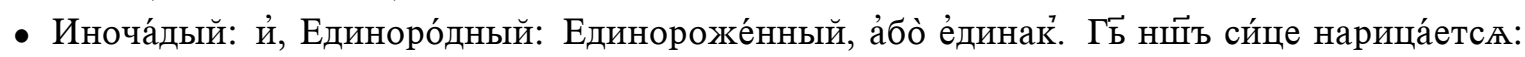

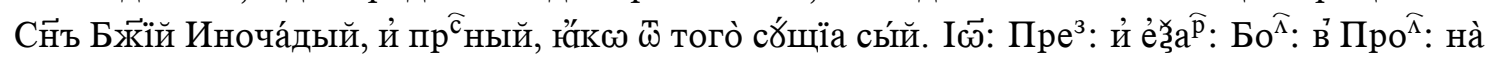
$\mathrm{Tо}^{\widehat{\Lambda}}: \mathrm{Ev}^{\widehat{\Gamma}}:\langle\vec{\Pi} \Theta, 49>$

Ioan Gură de Aur (vezi Mărgăritare mai jos):

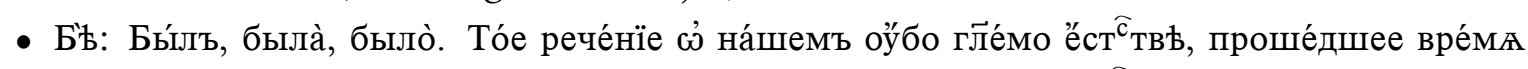

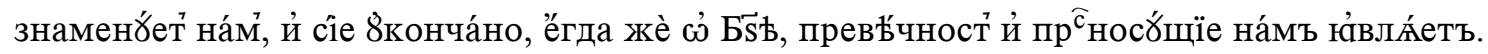

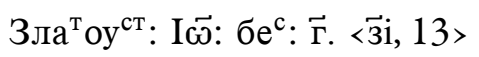

- Вреди́тель: шко́дца, кото́рый нар8ша́е

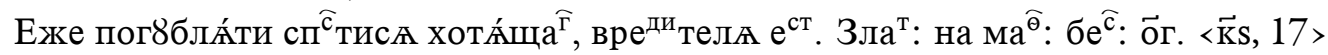

- До́ндеже: Ажъ по́ки: и́ ть́жъ на́въки, а̋жбымъ: а̋лбо по́ки а̋жъ, а̉бò ăжъ. Оббы́чай Писа́нїю

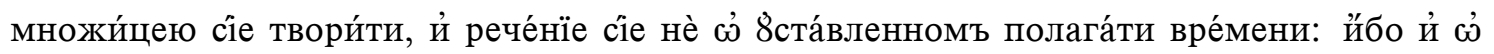
Ковче́зъ речѐ: Не възврати́сґ вра́нъ до́ндеже йсшѐ земл令 а̋ще й ни́же по̀ си́хъ възврати́сґ.

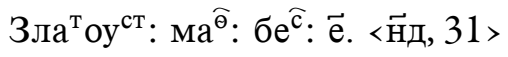


Chiril al Alexandriei:

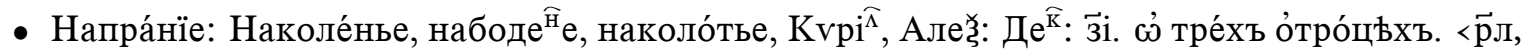
69>

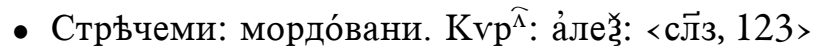

Chiril al Ierusalimului:

- БЪжде́нї: Прим8ше ${ }^{\widehat{H}}$ e. $\operatorname{Kvp}^{\widehat{\Lambda}} \operatorname{Iep}^{\widehat{c}} \Gamma^{\widehat{\Lambda}}$ ëi. $<\overline{и i}>$

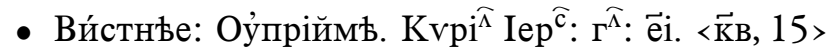

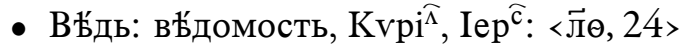

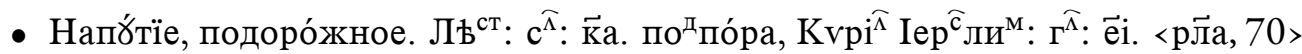

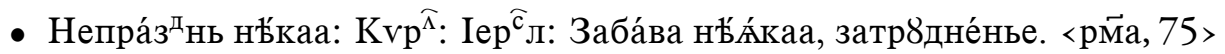

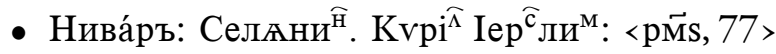

- Подо́бство: Подобе ${ }^{\widehat{H}}$ ство. Kvpi ${ }^{\widehat{\Lambda}} \operatorname{Iep}^{\widehat{c}}:\left\langle\mathrm{p}^{\widetilde{B}}\right.$, 85>

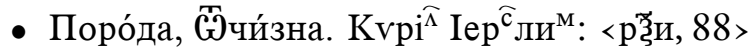

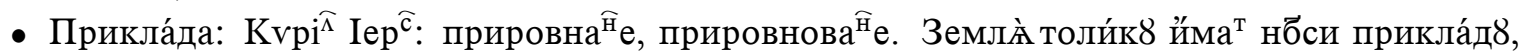
е́ли́ка сре́да коле́снаа къ всемй о́крйжїю. <рп̆з>

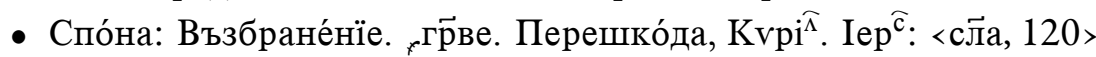

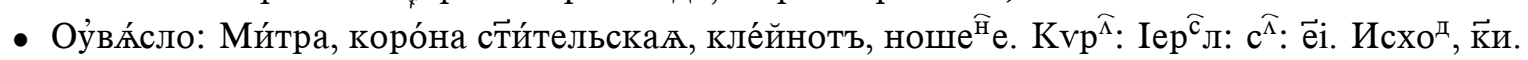
<с Зुम, 136>

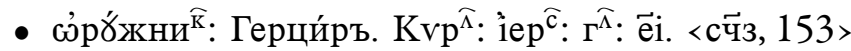

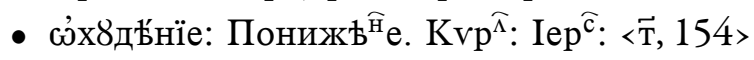

Nikephoros Kallistos (e posibil să fie vorba de Evanghelia didactică):

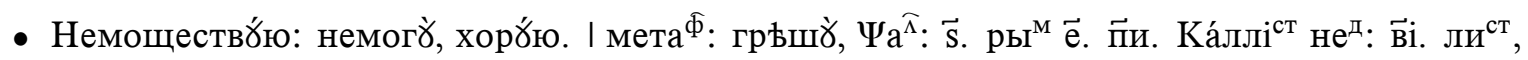

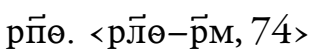

Cornucopie (probabil că se referă la ediția cărții lui Niccolò Perotti Cornucopie / Cornu Copie):

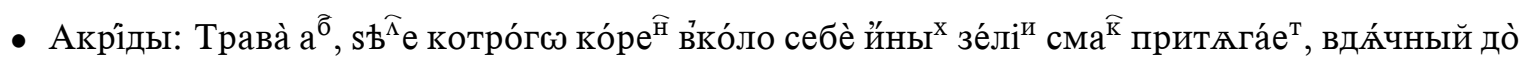

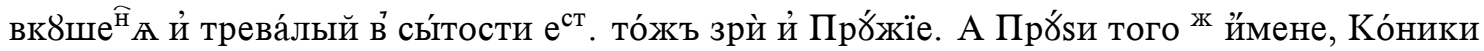

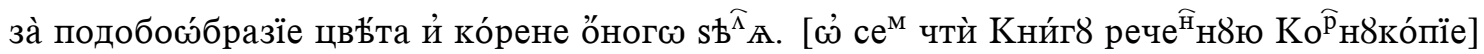

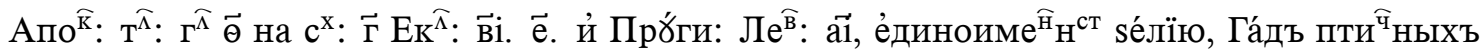
разли́чна ро́да. <тёз, 173>

Scara Raiului a lui Ioan Scărarul:

- Въсплища́ю: Засмйч8ю. ль $\mathrm{b}^{\widehat{c}}: \mathrm{c}^{\widehat{\Lambda}} . \vec{\Gamma} .<\overrightarrow{\pi s}, 22>$

- Гребло̀ Корми́лное: Сть́ръ, ко́рма. Лъ ${ }^{\text {ст }}: \mathrm{C}^{\widehat{\Lambda}}: \overrightarrow{3} \mathrm{i} .<\widehat{\mathrm{M}} 3,28>$

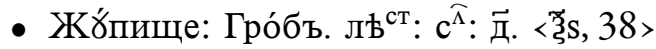

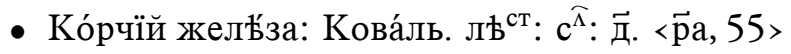

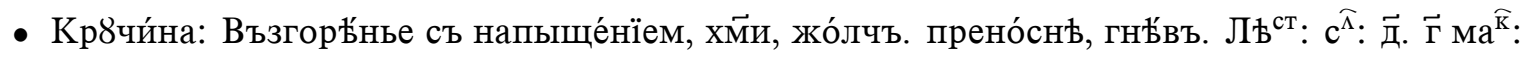
ё. $\langle\overrightarrow{\mathrm{p}}$ д, 56>

- ЛАдина̀: По́ле, Лъ ${ }^{\text {ст }}: \mathrm{C}^{\widehat{\Lambda}}:$ е $.<\mathrm{p} \not \mathrm{i}, 61>$

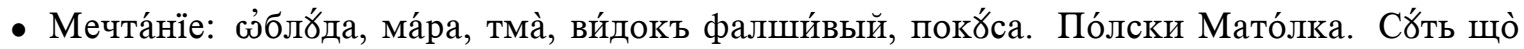
лю́демъ слб́жатъ, в Ла́пїи, в шве́цїи, поки́бы. мечта́нье: помышле́нье, а̋лбо ме́че ${ }^{\mathrm{T}}$, ацкд:

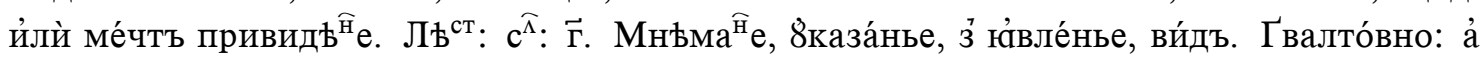

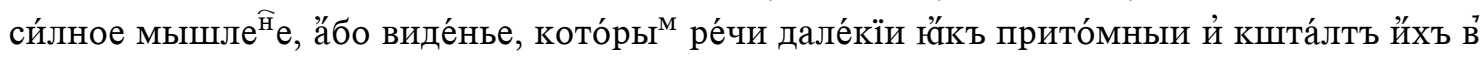

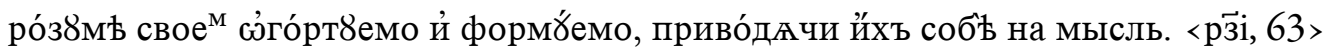

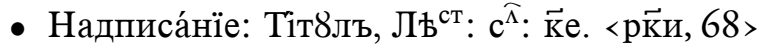

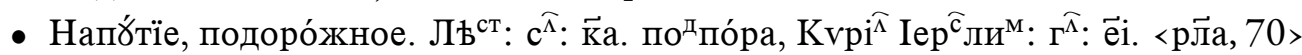




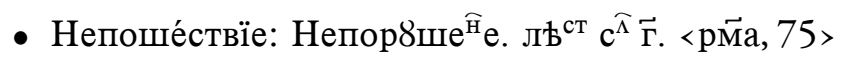

- Нова́къ: Новицїа́т, Лъ ${ }^{\text {ст }} \mathrm{c}^{\widehat{\Lambda}}: \vec{Д} .<\mathrm{p} \overrightarrow{\mathrm{M}} 3,78>$

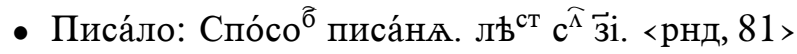

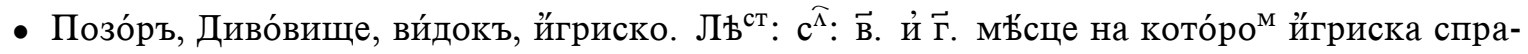
во́ваны быва́ютъ. <р苯, 86>

- Пони́вица: Р8чни ${ }^{\widehat{K}}$. Лъ ${ }^{\text {ст. }}: \mathrm{C}^{\widehat{\Lambda}}: \vec{Д} .\left\langle\mathrm{p}^{\widetilde{3}} 3,88>\right.$

- По́ртище: С8кно̀. Лъ ${ }^{\text {ст }: ~} \mathrm{C}^{\widehat{\Lambda}}: \overrightarrow{3} \mathrm{i} .<\mathrm{p}^{\mathfrak{x}} \Theta, 89>$

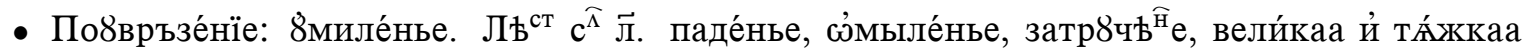
с’́ппа́лость. <рӧв, 90>

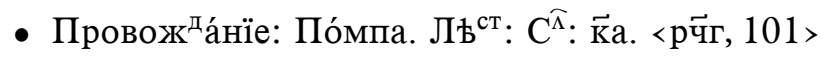

- Прозїлва́ю: Позъва́ю, Лъ ${ }^{\text {ст }} \mathrm{C}^{\widehat{\Lambda}} \overrightarrow{3}$ i. <рч

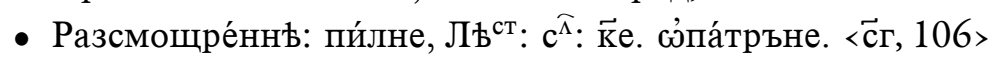

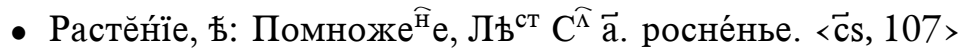

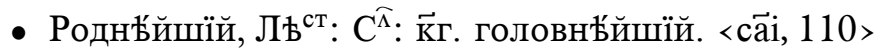

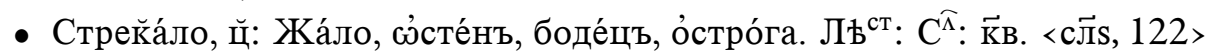

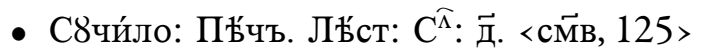

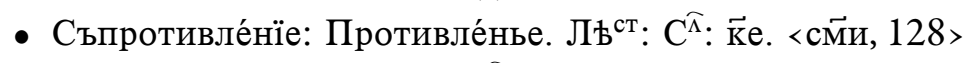

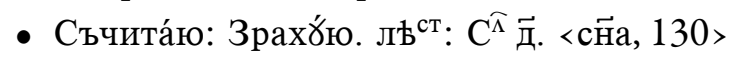

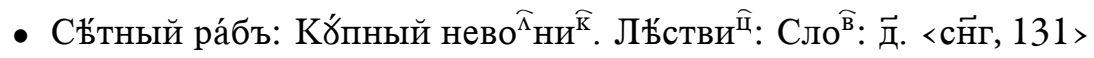

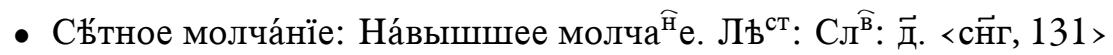

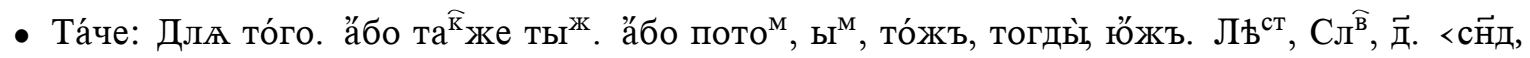
131>

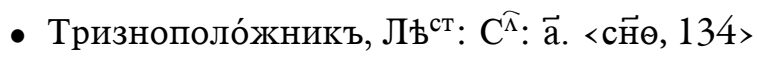

Maxim Grecul:

- Ва́снь: хра́пъ, мнъ̆нье. Сна́ть, ба́чъ, ве́й, нема́ль, не́гли, II нЊืчто. Сіии посло́вицъ, ёди́нъ

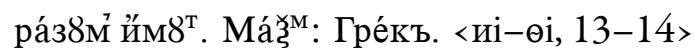

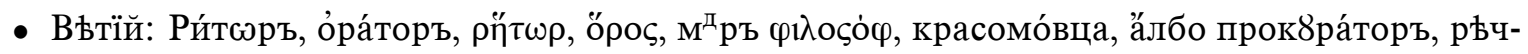
ни́къ, хитросло́вецъ. Мазّ̧ : <м, 24>

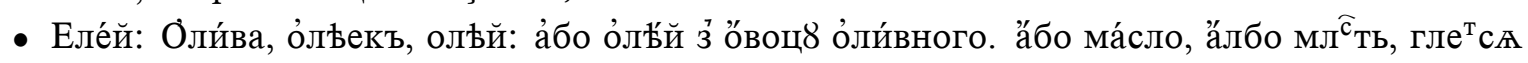

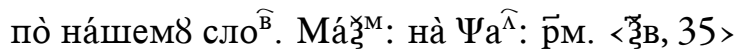

- Жела́нїе: ПрагнЊ̈нье, жаданье, пожадли́вость, хช̆ть, хти́во ${ }^{\text {ст }}$, и́лѝ по́хо ${ }^{\mathrm{T}}$, Крайнъ̌йше про́-

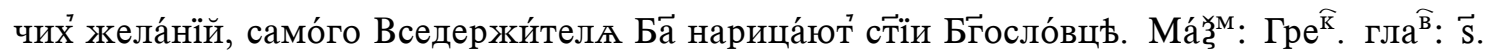
<३зд, 36>

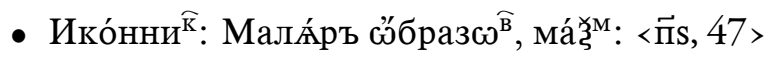

- Исто́чникъ: Здро́й, жрб̆дло, а̋бо крыни́цА. Мета ${ }^{\Phi}$ : Исаїа пр ${ }^{\widehat{0}}$ ркъ, йсто́чни ${ }^{\widehat{K}}$ прозыва́етъ

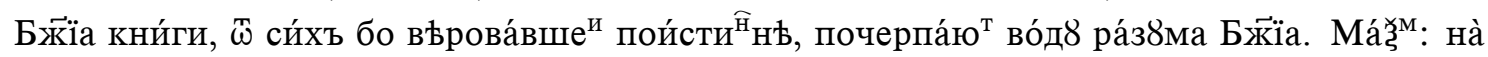
йсáïю. 〈 Ч Г, 51>

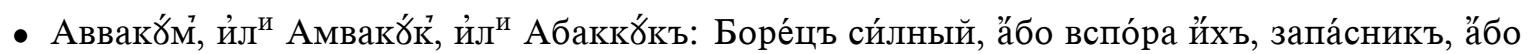

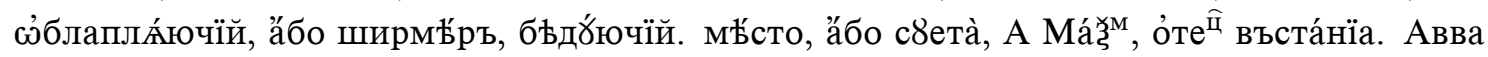

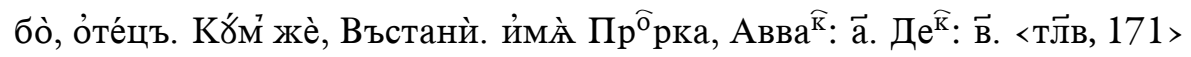

\section{Mărgăritare (Ioan Gură de Aur, Cartea numită Mărgăritare):}

- Сб́ета: Ма́рность, нђкче́мно ${ }^{\text {ст }}$, поро́жность, даре́мность. мета ${ }^{\Phi}:$ По́длость, де́шевость,

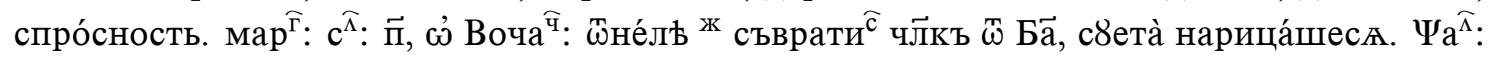

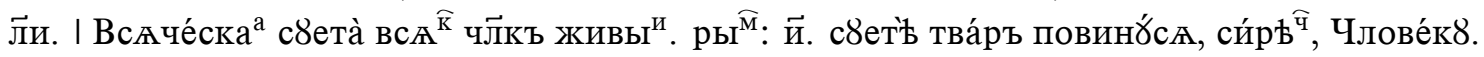
$\langle\overrightarrow{\mathrm{CM}}, 124\rangle$

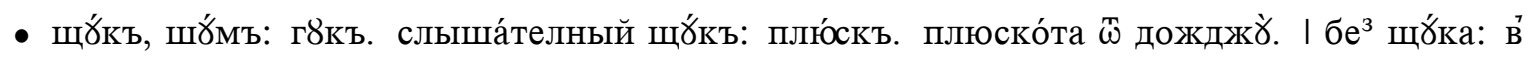

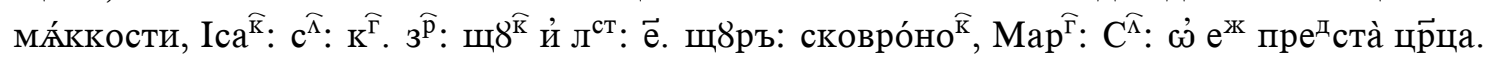


$\langle\overrightarrow{\mathrm{T} \theta}-\overrightarrow{\mathrm{T}} \mathrm{i}, 159\rangle$

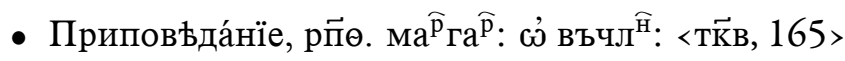

- Авра́мъ: Ӧте́ц выне́слый. а̋бо о ${ }^{\widehat{\Perp}}$ высо́кїй. а̋бо Прише́лец̉, прише́лни ${ }^{\widehat{\mathrm{K}}}$. прихо́день. Сы ${ }^{\widehat{ }}$

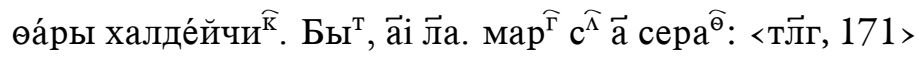

Nicon de la Muntele Negru:

- Водова́жда: Капа ${ }^{\widehat{p}}$ Смо́к што̀ во́д8 вытАга́ет̉ в̉ горஜ̆, й те́жъ ж8раве́ль: Напра́ви Водова́жд8 напаА́ти но́щїю село̀. Hi $^{\widehat{\mathrm{K}}}$ : $\mathrm{c}^{\widehat{\Lambda}}: \overrightarrow{3} \mathrm{i}$. $\langle\overrightarrow{\mathrm{K}} д, 16>$

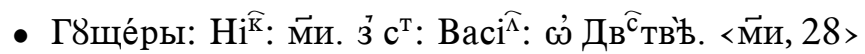

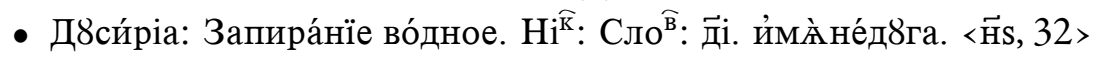

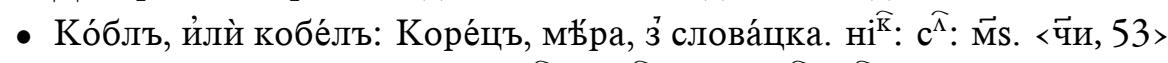

- Корва́нъ: Да́ръ, а̋бо о’фђрова ${ }^{\widehat{\mathrm{H}}} \mathrm{e} \cdot \mathrm{мa}^{\widehat{\mathrm{p}}}: \overrightarrow{3}$. $\overrightarrow{\mathrm{a}} \cdot \mathrm{Hi}^{\widehat{\mathrm{K}}}: \mathrm{C}^{\widehat{\Lambda}}: \overrightarrow{\mathrm{M}} \Theta .\langle\overrightarrow{\mathrm{p}}, 54>$

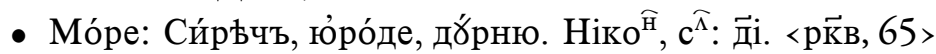

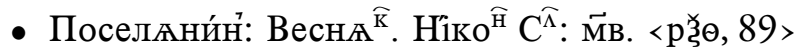

- ПотА́жни ${ }^{\widehat{\mathrm{K}}}$, й потА́жбы. $\mathrm{Hi}^{\widehat{\mathrm{K}}}: \mathrm{C}^{\widehat{\Lambda}}:$ Л̆ $\mathrm{s} .<\mathrm{pöB}, 90>$

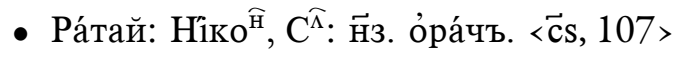

- Сланй́токъ: Кваше́нье, $\mathrm{Hi}^{\widehat{\mathrm{K}}}: \mathrm{c}^{\widehat{\Lambda}}: \overrightarrow{\mathrm{M}}$. $<$ скекг, 116>

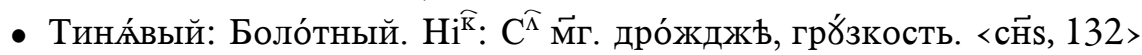

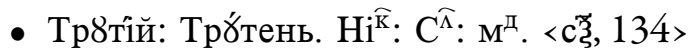

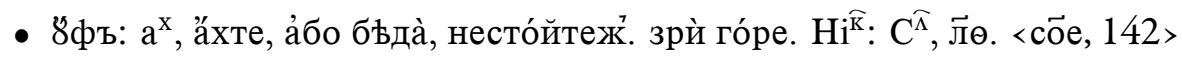

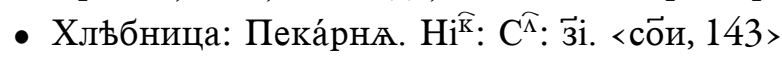

- Кёзнаръ: $\mathrm{Hi}^{\widehat{\mathrm{K}}}: \mathrm{C}^{\widehat{\Lambda}}: \overrightarrow{\mathrm{M}} \mathrm{e} .<\mathrm{TB} \mathrm{B}, 160>$

- Армé芯, $8 \mathrm{c}^{\mathrm{T}}: \Gamma^{\widehat{\Lambda}}, \vec{\jmath} a . \mathrm{Hi}^{\widehat{\mathrm{K}}}, \mathrm{c}^{\widehat{\Lambda}} \cdot \overrightarrow{\mathrm{H}} \cdot<\mathrm{T} \overrightarrow{\mathrm{H}}, 180>$

Patericul de schit:

- Дйхъ пүөо́нскїй, Па ${ }^{\mathrm{T}}:$ ск $^{\mathrm{T}}: \mathrm{c}^{\widehat{\Lambda}}:\langle\overrightarrow{\mathrm{H}} 3\rangle$

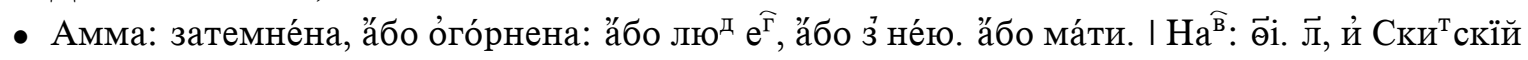
патерї̈ <т $\overrightarrow{\mathrm{M}}-\mathrm{T} \overrightarrow{\mathrm{M}} \mathrm{a}, 175>$

Patericul de făcătorilor de minuni de la Solovki (probabil, Viața lui Zosima și a lui Savatie din Solovki):

- КлАпи́на: ВсÁкое дре́во нагне́ное, Моско́вски нарица́етсА, Патери ${ }^{\widehat{K}}$ Солове́цки ${ }^{\mathrm{x}}$ ч8дот-

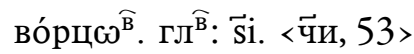

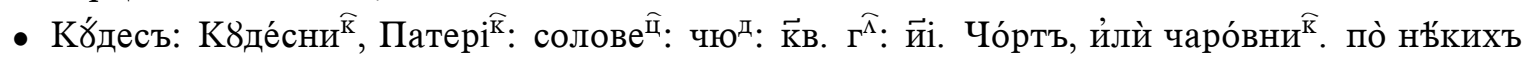

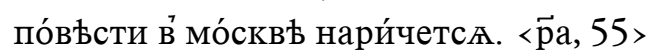

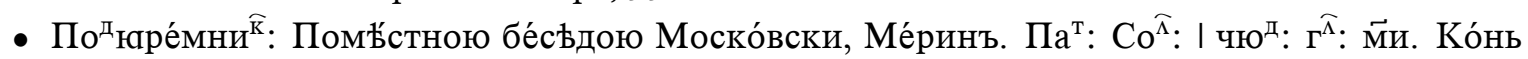

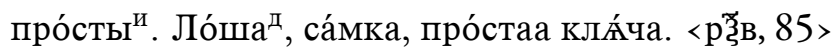

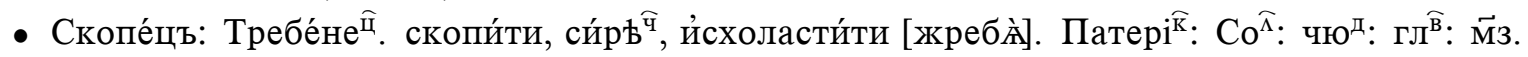
$\langle$ скйa, 115>

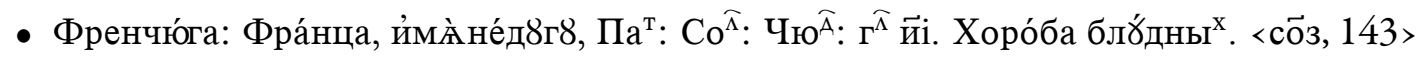

Tipicul (posibil, tipicul mănăstiresc al lui Iosif de Voloțk în redacție extinsă inclusă în Marile Minee de lectură, vezi Kalugin, 2014, p. 199):

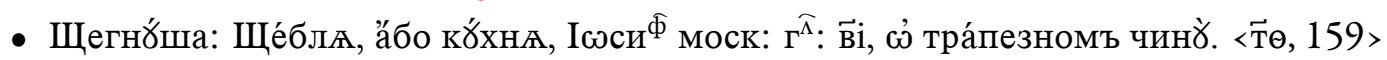

- Арме́ $\mathbb{\AA}, 8 \mathrm{c}^{\mathrm{T}}: \Gamma^{\widehat{\Lambda}}, \vec{\jmath} a . \mathrm{Hi}^{\widehat{\mathrm{K}}}, \mathrm{c}^{\widehat{\Lambda}} \cdot \mathrm{H} \overrightarrow{3} .<\mathrm{TH}, 180>$

- Лихои́мство, йлѝ лихоимถ̆нїе: ёст̉, всѐ е̋же и́зли́шнее, й па́че потре́бы. Ап

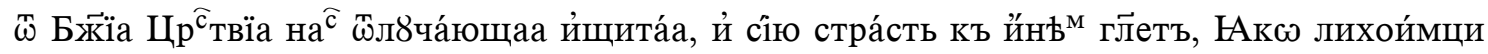

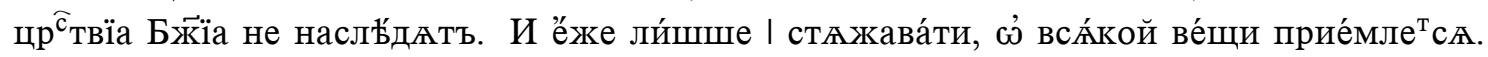
$8 \mathrm{cra}^{\widehat{B}} \Gamma^{\widehat{\Lambda}}:$ ла. 


\section{Concluzii}

Lista adusă mai sus nu poate fi considerată exhaustivă. De asemenea, Lexiconul conține o mulțime de referințe la Biblie, Evanghelie și Apostol. O parte din material, după cum am menționat în paginile anterioare, a fost preluată de către Berînda din Lexisul lui Lavrentii Zizanii, precum și din Onomasticonul anexat la Biblia din Anvers. Compunerea unui indice complet de izvoare constituie sarcina viitorilor editori ai Lexiconului; totodată, sperăm că informațiile conținute în acest studiu vor contribui la identificarea de către cercetătorii scrierilor lui Pamvo Berînda a listei complete a tuturor citatelor din Lexicon.

Din lista prezentată se observă faptul că Berînda a folosit în Lexiconul său, în primul rînd, edițiile tipărite la care a contribuit el însuși, și anume Comentariul la Faptele Sfinților Apostoli, Comentariul la cele 14 Epistole ale Sfintului Apostol Pavel de Ioan Gură de Aur și Evanghelia didactică. În același timp, a fost interesat și de izvoare lexicografice; alături de Lexis și Onomasticon, pe care le-am menționat mai sus, acestea includ Tălmăcirea vorbelor greu de ințteles pentru Scara Raiului și Tălmăcirea numelor după alfabet de Maxim Grecul. Materialele Lexiconului lui Berînda au fost ulterior utilizate, printre altele, la întocmirea Azbukovnikului din Solovki de Serghie Șelonin. Pentru lexicografi, cunoașterea surselor Lexiconului lui Berînda va fi utilă pentru identificarea citatelor ascunse în materialele (az)bucoavnelor și ale lexicoanelor alcătuite ulterior.

\section{Bibliografie}

Alekseev, M.P. (1968). Словари иностранньх слов в русском азбуковнике ХVII века: Исследование, тексты и комментарии, Наука, Leningrad.

Arkhangel'skiї, А.С. (1902). Памва Берында, în Русский биографический словарь: Павел, преподобньй - Петр (Илейка), ediție sub coordonarea președintelui Societății Imperiale Ruse de Istorie, A. A. Polovțov, vol. 13, tipografia lui I.N. Skorohodov, Sankt-Petersburg, p. 164-168.

Janów, J. (1951). Leksikografia wschodno-stowiańska do końca XVII w. Cz. II, 2. Etymologie Maksyma Greka, ManuelaRetora i innych autorów w stowniku imion P. Beryndy z 1627 r., în „Sprawozdania z czynności i posiedzeń Polskiej Akademii Umiejętnošci”, LII (6), p. 466-474.

Kalugin, V.V. (2014), Сочинения Максима Грека в “Аексиконе славеноросском” Памвь Берьндыь, în „Россия и Христианский Восток. Nr. IV-V”, Limbile culturii slavone, Moscova, p. 189-201.

Kovtun, L.S. (1963). Русккаялексикография эпохи Средневековъя, Editura Academiei de Științe a URSS, Moscova/Leningrad.

Kuzminova, E.A. (2000). Грамматика Ааврентия Зизания и Мелетия Смотрицкого, ediție, comentariu și note de $\sim$, prefața de E. A. Kuzminova, M.L. Remniova, Editura Universității de Stat din Moscova, Moscova/Leningrad.

Nimciuk, V.V. (1961). Памво Беринда і його “Аексиконъ славенорсосскій и именъ тлькованїе”, în Аексикон словеноросьский Памви Беринди, ediție și prefață de V.V. Nimciuk, Editura Academiei de Științe a RSS Ucrainene, p. V-XXXVI. 